\title{
THE DISTRIBUTION OF SOME SERUM PROTEIN AND RED CELL ENZYME POLYMORPHISMS IN THE KOCH ETHNIC GROUP OF WEST BENGAL, INDIA
}

\author{
N. SAHA, ${ }^{1}$ J.S.H. TAY, ${ }^{1}$ M.K. DAS, ${ }^{2}$ K. DAS, ${ }^{2}$ M. RoY, ${ }^{2}$ \\ B. DeY, ${ }^{2}$ S. BANERJEe, ${ }^{2}$ and B.N. MukHerJeE ${ }^{2}$ \\ ${ }^{1}$ Department of Paediatrics, Genetics Division, National University of Singapore, \\ Singapore \\ ${ }^{2}$ Anthropometry and Human Genetics Unit, Indian Statistical Institute, \\ Calcutta 700035, India
}

\begin{abstract}
Summary Three populations (Poliya, Deshi, and Tiyor) of the Koch ethnic group have been studied for the distribution of three serum protein and four red cell enzyme polymorphisms. There was no significant difference in the allelic frequencies of these systems in the three populations of the Koch ethnic group. The overall gene frequencies were as follows: $H p^{1}, 0.21 ; G c^{1 \mathrm{~F}}, 0.34 ; G c^{1 \mathrm{~s}}, 0.36 ; G c^{2}, 0.30 ; T f^{\mathrm{c} 1}, 0.66 ; T f^{\mathrm{c} 2}, 0.26 ; T f^{\mathrm{c} 3}$, $0.001 ; T f^{\mathrm{D}}, 0.06 ; G L O^{1}, 0.21 ; P G I^{2}, 0.04 ; A K^{2}, 0.01 ; P G M^{1+}, 0.80 ; P G M^{1-}$, $0.06 ; P G M^{2+}, 0.11$ and $P G M^{2-}, 0.02$. The phenotypic distribution at all the loci was at Hardy-Weinberg equilibrium.
\end{abstract}

Key Words mongoloid population, blood genetic markers, haptoglobin, transferrin and Gc subtypes, phosphoglucomutase subtypes, PoliyaDeshi, Tiyor

\section{INTRODUCTION}

The Koch ethnic group of eastern India represents a tribe-caste continuum in the Hindu social system of India. They are a Mongoloid group in the northern part of the present West Bengal and Assam states who have been described as being one of the most ancient peoples of India (Dalton, 1872). The Poliya, Deshi and Tiyor populations of the present investigations originated from the original Koch ethnic group. The Poliya and Deshi are Bengali-speaking while the Tiyors speak Khotta or a mixed Hindi dialect. Poliyas are traditionally horticulturists while the Deshis are settled agriculturists. They have probably been admixed with certain Caucasoid castes from time to time. It therefore appears that the Koch ethnic group offers an interesting population for genetic studies.

Received May 25, 1990; revised version received July 10, 1990; Accepted July 20, 1990. 
We present here the distribution of three serum protein markers in the Poliya, Deshi and Tiyor subdivisions of the Koch and four red cell enzyme polymorphisms in a small group comprised of the Poliya and Deshi.

\section{MATERIALS AND METHODS}

Samples of blood were collected from 240 individuals of both sexes from the Koch ethnic group of the Malda district of West Bengal, eastern India by fingerprick into heparinised Eppendorf tubes. Only a limited number of red cell enzyme systems could be studied in sample sizes varying from 55 to 108 from the Poliya and Deshi. The details of the methods were the same as those described earlier (Saha, 1987a).

\section{RESULTS AND DISCUSSION}

The distribution of three serum protein polymorphism in the Koch ethnic groups is presented in Table 1.

\section{Serum proteins}

Similar frequencies of haptoglobin alleles were observed in the Poliya, Deshi and Tiyor populations of the Koch ethnic group with a range of $H p^{1}$ varying from 0.19 to 0.24 . Mukherjee et al. (1987) have reported a $H p^{1}$ frequency of 0.35 in the related Rajbanshis of West Bengal which is higher than that in the other nine populations. The frequencies of $G c^{1 \mathrm{~F}}$ have been found to range from 0.30 to 0.35 which falls within the reported frequencies of the allele in the Mongoloid population of eastern India (Saha, 1987a; Walter et al., 1986). The Mongoloid population of South East Asia, the Chinese and Japanese have much higher frequencies of $G c^{1 F}$ (Saha, 1989a). The frequencies of $G c^{1 \mathrm{~s}}$ varied from 0.35 to 0.38 which are in agreement with the reported frequency of $G c^{1 \mathrm{~s}}$ in the Mongoloid population of eastern India. The Mongoloid population of South East Asia as well as East Asia have a much lower $G c^{1 \mathrm{~s}}(0.15$ to 0.33$)$. A much higher frequency of $G c^{1 \mathrm{~s}}$ has been reported in north and south India. Frequency of $G c^{2}$ varied from 0.20 to 0.34 in the three populations of the Koch ethnic groups which is slightly higher than that reported in the Caucasoid population of northern and western India as well as the Dravidian populations. The frequencies of $T f^{\mathrm{c} 1}$ and $T f^{\mathrm{c} 2}$ were found to be 0.69 and 0.24 in the Poliya compared to 0.63 and 0.30 in the Deshi. $T f^{\mathrm{Dohi}}$ was found to be 0.06 in both the Poliya and Deshi. A much lower frequency of $T f^{\mathrm{C} 1}$ has been observed in the Assamese and Manipuri (0.54) with corresponding higher $T f^{\mathrm{c} 2}$ (0.42 to 0.45) (Walter et al., 1986). The Mongoloids of East and South-east Asia have much higher frequencies of $T f^{\mathrm{Cl}}$ (Saha, 1987b).

\section{Red cell enzymes}

The distribution of four red cell enzymes in the Koch ethnic group is presented in Table 2. 
Table 1. Distribution of serum porteins in Poliya, Deshi and Tiyor of the Koch ethnic group of West Bengal, India.

\begin{tabular}{|c|c|c|c|c|c|c|c|c|c|c|}
\hline \multirow{3}{*}{ Systems } & \multirow{3}{*}{ Phenotypes } & \multicolumn{4}{|c|}{ Populations } & \multicolumn{5}{|c|}{ Gene frequencies } \\
\hline & & \multirow{2}{*}{$\frac{\text { Poliya }}{\mathrm{N}}$} & \multirow{2}{*}{$\frac{\text { Deshi }}{\mathrm{N}}$} & \multirow{2}{*}{$\begin{array}{c}\text { Tiyor } \\
\mathrm{N}\end{array}$} & \multirow{2}{*}{$\frac{\text { All }}{\mathrm{N}}$} & & \multirow{2}{*}{ Poliya } & \multirow{2}{*}{ Deshi } & \multirow{2}{*}{ Tiyor } & \multirow{2}{*}{ All } \\
\hline & & & & & & & & & & \\
\hline \multirow[t]{4}{*}{ Haptoglobin } & $1-1$ & 2 & 4 & 2 & 8 & $H p^{1}$ & 0.2113 & 0.2436 & 0.1923 & 0.2146 \\
\hline & $2-1$ & 26 & 30 & 31 & 87 & $H p^{2}$ & 0.7887 & 0.7564 & 0.8077 & 0.7854 \\
\hline & $2-2$ & 43 & 44 & 58 & 145 & & & & & \\
\hline & All & 71 & 78 & 91 & 240 & & & & & \\
\hline \multirow{7}{*}{$\begin{array}{c}\text { Group-specific } \\
\text { component }\end{array}$} & $1 \mathrm{~F}$ & 7 & 12 & 16 & 35 & & & & & \\
\hline & $1 \mathrm{~F} 1 \mathrm{~S}$ & 17 & 20 & 13 & 50 & $G c^{1 \mathrm{~F}}$ & 0.3000 & 0.3598 & 0.3494 & 0.3383 \\
\hline & is & 8 & 10 & 12 & 30 & $G c^{1 \mathrm{~S}}$ & 0.3571 & 0.3780 & 0.3554 & 0.3638 \\
\hline & IF2 & 11 & 15 & 13 & 39 & $G c^{2}$ & 0.3429 & 0.2622 & 0.2952 & 0.2979 \\
\hline & $1 \mathrm{~S} 2$ & 17 & 22 & 22 & 61 & & & & & \\
\hline & 2 & 10 & 3 & 7 & 20 & & & & & \\
\hline & All & 70 & 82 & 83 & 235 & & & & & \\
\hline \multirow[t]{9}{*}{ Transferrin } & $\mathrm{C} 1-\mathrm{C} 1$ & 35 & 28 & & 63 & & & & & \\
\hline & $\mathrm{C} 2-\mathrm{C} 1$ & 23 & 38 & & 61 & $T f^{\mathrm{Cl}}$ & 0.6901 & 0.6296 & & 0.6579 \\
\hline & $\mathrm{C}_{2}-\mathrm{C}_{2}$ & 4 & 4 & & 8 & $T f^{\mathrm{C} 2}$ & 0.2394 & 0.3025 & & 0.2632 \\
\hline & $\mathrm{C} 1-\mathrm{C} 3$ & 0 & 1 & & 1 & $T f \mathrm{Cs}$ & 0.0070 & 0.0062 & & 0.0066 \\
\hline & $\mathrm{C} 2-\mathrm{C} 3$ & 1 & 0 & & 1 & $T f \mathrm{D}$ & 0.0634 & 0.0617 & & 0.0625 \\
\hline & C1-D & 5 & 7 & & 12 & & & & & \\
\hline & C2-D & 2 & 3 & & 5 & & & & & \\
\hline & DD & 1 & & & 1 & & & & & \\
\hline & All & 71 & 81 & & 152 & & & & & \\
\hline
\end{tabular}

Table 2. Distribution of red cell glyoxalase, adneylate-kinase, glucose phospho-isomerase and phosphoglucomutase (1) in the Koch ethnic group of West Bengal, India.

\begin{tabular}{|c|c|c|c|c|}
\hline \multirow{2}{*}{$\begin{array}{l}\text { Systems } \\
\text { Glyoxalase I }\end{array}$} & \multirow{2}{*}{ Phenotypes } & \multirow{2}{*}{$\frac{N}{5}$} & \multicolumn{2}{|c|}{ Gene frequencies } \\
\hline & & & $G L O^{1}$ & 0.2083 \\
\hline & $2-1$ & 35 & $G L O^{2}$ & 0.7917 \\
\hline & $2-2$ & 68 & & \\
\hline & A.11 & 108 & & \\
\hline \multirow{3}{*}{ Phosphoglucose isomerase } & $1-1$ & 61 & $P G I^{1}$ & 0.9621 \\
\hline & $2-1$ & 5 & $P G f^{2}$ & 0.0379 \\
\hline & All & 66 & & \\
\hline \multirow[t]{3}{*}{ Adenylate-kinase } & $1-1$ & 77 & $A K^{1}$ & 0.9936 \\
\hline & $2-1$ & 1 & $A K^{2}$ & 0.0064 \\
\hline & All & 78 & & \\
\hline \multirow[t]{9}{*}{ Phosphoglucomutase (locus 1) } & $1+$ & 38 & $P G M^{1+}$ & 0.8000 \\
\hline & $1+1-$ & 3 & $P G M^{1-}$ & 0.0636 \\
\hline & $1-$ & 1 & $P G M^{2+}$ & 0.1091 \\
\hline & $1+2+$ & 8 & $P G M^{2-}$ & 0.0182 \\
\hline & $1+2-$ & 1 & $P G M$ & 0.0091 \\
\hline & $1-2+$ & 2 & & \\
\hline & $2+$ & 1 & & \\
\hline & $2-y$ & 1 & & \\
\hline & All & 55 & & \\
\hline
\end{tabular}


The frequency of $G L O^{1}$ was found to be 0.21 which is similar to the $G L O^{1}$ frequencies in other Indian population ( 0.15 to 0.24$)$. The frequency of $P G I^{2}$ and $A K^{2}$ was very low in the Koch ethnic group ( 0.04 and 0.01 respectively). $A K^{2}$ is much lower than that reported in most of the populations of India, reaching 0.11 in the Assamese.

The frequencies of $P G M^{1+}$ and $P G M^{1-}$ were found to be 0.80 and 0.06 respectively. The $P G M^{1+}$ frequency is rather high compared to that in the populations of South and East Asia (Saha, 1988). The $P G M^{2+}$ frequency of 0.11 is correspondingly lower.

The above gene frequencies at seven polymorphic loci suggest a strong Mongoloid characteristic of the Koch ethnic group as suggested by a high $G c^{1 . F}$ and $T f^{\text {DChi }}$ and a low $G L O^{1}$ and $A K^{2}$.

Acknowledgments The authors are grateful for excellent technical assistance by Miss Jumiah Bte Basair and secretarial assistance by Miss Tay Siew Leng. The project was generously supported by the Singapore Turf Club and Shaw Foundation.

\section{REFERENCES}

Dalton, E.T. 1872. Descriptive ethnology of Bengal. Calcutta Govt. of Bengal Printings.

Mukherjee, B.N., Walter, H., Malhotra, K.C., Chakraborty, R., Sauber, P., Banerjee, S. and Roy, M. 1987. Population genetic study in ten endogamous groups of West Bengal. Anthropol. Anz. 45: 239-254.

Saha, N. 1987a. Blood genetic markers in Bengali Muslims of Bangladesh. Hum. Hered. 37: $86-93$.

Saha, N. 1987b. Distribution of transferrin (Tf) subtypes in several Mongoloid populations of East Asia. Anпu. Hum. Biol. 12: 349-356.

Saha, N. 1988. Distribution of phosphoglucomutase-I subtypes in several Mongoloid populations of East Asia. Am. J. Phys. Anthropol. 77: 91-96.

Saha, N. 1989a. Distribution of group-specific component (Gc) subtypes in several Mongoloid populations of East Asia. Annu. Hum. Biol. 16: 53-60.

Saha, N. 1989b. Blood genetic markers in the Chinese of two Eastern provinces. Am. J. Phys. Anthropol. 80: 295-303.

Walter, H., Mukherjee, B.N., Gilbert, K., Lindenberg, P., Dannewitz, A., Malhotra, K.C., Das, B.M. and Deka, R. 1986. Investigations on the variability of haptoglobin, transferrin and Gc polymorphisms in Assam, India. Hum. Hered. 36: 388-396. 